\title{
KEPEDULIAN MASYARAKAT TERHADAP ANCAMAN KERUSAKAN TERUMBU KARANG DI KECAMATAN SIKAKAP KABUPATEN KEPULAUAN MENTAWAI
}

\author{
Absyari Putri Nediya ${ }^{1}$, Triyatno ${ }^{2}$, Widya Prarikeslan ${ }^{3}$ \\ Pendidikan Geografi \\ Fakultas Ilmu Sosial Universitas Negeri Padang \\ Email: absyarinediya@gmail.com
}

\begin{abstract}
ABSTRAK
Penelitian ini bertujuan untuk memberikan informasi mengenai pemahaman, tindakan, sumbangan dan kepedulian masyarakat tentang ancaman kerusakan terumbu karang di Kecamatan Sikakap. Penelitian ini adalah penelitian kualitatif. Informan penelitian adalah masyarakat Kecamatan Sikakap yang dipilih menggunakan metode snowball sampling. Hasil penelitian yang diperoleh; 1) secara umum masyarakat telah mampu menjelaskan dengan baik arti dan fungsi terumbu karang, namun masih kurang menyadari ancaman yang dapat ditimbulkan terhadap kelangsungan hidup terumbu karang. 2) Sumbangan masyarakat terhadap kelangsungan hidup terumbu karang hanya dalam bentuk moril saja sedangkan materil tidak. 3) Tindakan masyarakat terhadap sebab-sebab kerusakan terumbu karang yaitu penyalahgunaan alat tangkap perikanan, pencemaran laut oleh sampah rumah tangga, penambangan karang, dan aktivitas perahu. 4) Kepedulian masyarakat terhadap ancaman kerusakan terumbu karang lebih ditunjukkan oleh masyarakat yang bertempat tinggal di perkampungan.
\end{abstract}

Kata Kunci: Kepedulian, Ancaman Kerusakan, Terumbu Karang

\section{ABSTRACT}

This research of aims are provided informations on understanding, actions, contributions and public careness about the threat of coral reef damage in Sikakap subdistrict. This research is a qualitative research. The research informant is the Sikakap subdistrict people selected by the snowball sampling method. The results obtained 1) generally, public has been able to explain well the meaning and function of the coral reefs, but they still not aware of the threats can be impact to the survival of coral reefs. 2) Public contributions to the survival of coral reefs are only in moral, form while materil is nonexistent. 3) Public actions on the causes of damage to coral reefs is abuse of fishing gear, sea pollution by household waste, exploitation of corals and boat activities. 4) Public careness to the threat of coral reef damage is more showed by the people who lived in the village.

Keywords: Careness, Threat of Damage, Coral Reefs

\footnotetext{
${ }^{1}$ Artikel ini ditulis dari skripsi penulis dengan judul Kepedulian Masyarakat terhadap Ancaman Kerusakan Terumbu Karang di Kecamatan Sikakap Kabupaten Kepulauan Mentawai untuk wisuda September 2018 dengan Pembimbing I ${ }^{2}$ Triyatno, S. Pd, M. Pd dan Pembimbing II ${ }^{3}$ Widya Prarikeslan, S.Si, M.Si
} 


\section{PENDAHULUAN}

Terumbu karang adalah endapan massive kalsium karbonat (kapur) yang diproduksi oleh binatang karang dengan sedikit tambahan dari alga berkapur dan organisme-organisme lain penghasil kalsium karbonat. Klasifikasi ilmiah menunjukkan bahwa karang ini termasuk kelompok binatang dan bukan sebagai kelompok tumbuhan. Binatang karang ini masuk ke dalam phylum Cnidaria, kelas Anthozoa, ordo Scleractina (amin, 2009). Zamani dan Madduppa (2011), menjelaskan bahwa hewan karang termasuk kelas Anthozoa, yang berarti hewan berbentuk bunga (Antho artinya bunga; zoa atinya hewan).

Terumbu karang merupakan salah satu bentuk kekayaan alam dan keunikan bawah laut yang mempesona. Hal ini dapat dilihat dari warna, bentuk serta keanekaragaman kehidupannya. Terumbu karang tidak hanya menyimpan sumber daya alam berupa keindahan saja, tetapi masih banyak potensi yang terkandung di dalamnya. Terumbu karang merupakan salah satu potensi sumber daya alam laut yang sangat penting dan strategis dalam kehidupan organisme yang sangat melimpah dimana terdapat lebih dari 4.000 spesies ikan, dan 2.500 jenis ikan karang yang mendiami kawasan laut dunia (Nash, 1989).

Terumbu karang dengan segala keanekaragaman biologisnya sangat berperan penting dalam berbagai hal. Terumbu karang menyediakan barang dan jasa yang bernilai ekonomis bagi manusia yaitu sebagai lokasi kegiatan penangkapan berbagai jenis biota laut konsumsi dan berbagai jenis ikan hias, sebagai bahan dasar konstruksi, dan juga sebagai objek kegiatan objek wisata bahari (Done, et al, 1996).

Dalam kenyataannya banyak kegiatan penangkapan ikan yang tidak ramah lingkungan memberikan ancaman terhadap terumbu karang. Terumbu karang secara terus menerus mendapat tekanan dari berbagai aktivitas manusia baik secara langsung maupun tidak langsung. Ancamanancaman ini sebagian besar merupakan hasil dari kenaikan penggunaan sumber daya pesisir oleh populasi pesisir yang berkembang secara cepat, ditunjang oleh kurangnya perencanaan dan pengelolaan yang tepat (Tesfamichael dan Pitcher, 2006).

Eksploitasi berlebihan dengan mengabaikan kaidah konservasi telah menimbulkan kerusakan terumbu karang di Indonesia. Moberg dan Folke (1999) menjelaskan bahwa kerusakan terumbu karang pada umumnya terjadi secara alami dan akibat kegiatan manusia. Adapun kegiatan manusia yang dapat mengakibatkan kerusakan pada terumbu karang diantaranya adalah pengambilan karang untuk bahan bangunan secara berlebihan, kegiatan untuk penangkapan ikan menggunakan alat tangkap yang tidak ramah lingkungan. Aktivitas manusia yang juga secara langsung dapat menyebabkan kerusakan terumbu karang diantaranya adalah pembuangan jangkar, penambangan batu karang, penambangan pasir dan sebagainya.

Sukmara (2001) menyebutkan bahwa sumber ancaman kerusakan E-ISSN : 2615-2630 
terumbu dari kegiatan illegal fishing yaitu: 1) penangkapan ikan dengan bom, 2) menyemprotkan racun dan potasium pada daerah yang menjadi tempat hidup ikan di sekitar terumbu karang, 3) penggunaan jaring dasar dan trawl yaitu alat tangkap ikan berupa jaring yang ditarik menggunakan kapal menyusuri permukaan dasar perairan, 4) penggunaan bubu secara berlebihan, yaitu alat tangkap ikan berupa jebakan berbentuk kurungan seperti ruang tertutup sehingga ikan tidak dapat keluar.

Selain kegiatan illegal fishing, permukiman penduduk yang semakin meluas memicu terjadinya pencemaran laut, karena semua limbah dari daratan pada akhirnya bermuara ke laut dan mencemari ekosistemnya termasuk terumbu karang. Djalal (1995) menyebutkan salah satu sumber pencemaran di laut adalah pembuangan kotoran dan sampah. Pembuangan sampah rumah tangga meningkatkan tingkat nutrisi dan racun di lingkungan terumbu karang. Pembuangan limbah yang tidak diolah terlebih dahulu ke laut menambah nutrisi dan pertambahan alga yang berlebihan. Limbah kaya nutrisi dari pembuangan atau sumber lain khususnya amat mengganggu karena dapat meningkatkan perubahan besar dari struktur terumbu karang secara perlahan dan teratur. Alga mendominasi terumbu hingga melenyapkan karang pada akhirnya (Dahuri dkk, 2008).

Kegiatan-kegiatan manusia di daerah pesisir yang terdapat ekosistem terumbu karang selain menyebabkan kerusakan fisik bagi karang, juga mempengaruhi integritas struktur Jurnal Buana - Volume-2 No-5 2018 karang. Salah satu kegiatan manusia yang menjadi penyebab utama kerusakan terumbu karang yaitu aktivitas penambangan karang. Berwich dalam Dahuri dkk (2008) menyebutkan bahwa penambangan karang dan pasir yang terdapat di daerah terumbu karang sebagai bahan pondasi bangunan akan merusak secara langsung fisik dari terumbu karang dan akan mengurangi pondasi dari terumbu karang.

Kegiatan kapal dapat berdampak buruk bagi terumbu karang melalui tumpahan minyak dan pembuangan dari kapal. Kerusakan fisik secara langsung dapat terjadi saat kapal membuang jangkar dan berlabuh secara tidak sengaja di permukaan karang (Dahuri, 2008). Sukmara (2001), menyebutkan bahwa sumber ancaman kerusakan terumbu karang oleh lalu lintas kapal diantaranya: 1) sauh atau jangkar kapal yang dibuang ke laut membentur permukaan karang secara terus menerus dan merusak permukaan terumbu karang, 2) kapal di perairan dangkal menyebabkan pergesekan sisi bawah kapal dengan dasar laut atau terumbu karang (kandas), 3) alat pendorong perahu yang menggunakan tongkat dan bertumpu pada dasar laut atau permukaan karang.

Analisis ancaman-ancaman yang potensial bagi terumbu karang dari manusia (pembangunan daerah pesisir, eksploitasi berlebihan, erosi dan polusi laut serta praktek perikanan yang merusak) di tahun 1998 memperkirakan $27 \%$ dari terumbu karang berada di tingkat beresiko tinggi (mengalami kerusakan) dan $31 \%$ lainnya berada pada resiko sedang (Westmacott dkk,

E-ISSN : 2615-2630 
2000). Atas dasar hasil penelitian tersebut jelas menunjukkan bahwa hampir sepertiga karang di Indonesia kualitasnya tergolong kurang baik, bahkan untuk wilayah Indonesia barat (termasuk daerah Mentawai).

Kecamatan Sikakap sebagai bagian dari administrasi Kepulauan Mentawai tentu tidak luput dari daerah dengan kualitas karang kurang baik tersebut. Analisis citra satelit Alos yang dilakukan oleh Suryaso (2011) menjelaskan luasan ekosistem terumbu karang di Kecamatan Sikakap disajikan pada tabel 1 .

Tabel 1. Luasan Ekosistem Terumbu Karang (dalam satuan ha)

\begin{tabular}{|l|l|l|l|}
\hline No & Kelas & Total (ha). & Persen \\
\hline 1 & Karang hidup & 9.552 & 5,50 \\
\hline 2 & Karang mati & 27.505 & 16,6 \\
\hline 3 & $\begin{array}{l}\text { Pecahan } \\
\text { karang }\end{array}$ & 26.269 & 15,8 \\
\hline 4 & $\begin{array}{l}\text { Substrat } \\
\text { campuran }\end{array}$ & 22.539 & 13,9 \\
\hline 5 & Pasir & 63.679 & 38,3 \\
\hline 6 & Rampart & 16.400 & 9,0 \\
\hline
\end{tabular}

Sumber: Suryarso (2011:102)

Selanjutnya

berdasarkan

monitoring terumbu karang yang dilakukan oleh Hukom dkk (2010) substrat dasar perairan stasiun pengamatan karang di Kecamatan Sikakap didominasi oleh pasir, patahan karang mati dan sedikit karang hidup. Kondisi karang hidup di lokasi pengamatan Kecamatan Sikakap masuk dalam kategori “jelek". Bandiyono dkk (2009) menyebutkan bahwa kegiatan perikanan menjadi salah satu penyebab kerusakan terumbu karang di Kecamatan Sikakap. Selain itu aktivitas sehari-hari masyarakat juga menjadi penyebab ancaman kerusakan terumbu karang di Kecamatan Sikakap.
Kerusakan terumbu karang dapat mengancam sumberdaya di wilayah pesisir dan laut seperti hilangnya daerah pemijahan dan mencari makan bagi biota laut serta berkurangnya ikan (Cicin-Sain et al., 1998). Selain itu dampak kerusakan lainnya yaitu hilangnya fungsi fisik terumbu karang seperti peredam gelombang dan pencegahan intrusi air laut (Christie dan White, 2007). Sebelum kerusakan semakin luas dan parah, selayaknya sikap dan perhatian yang besar kita curahkan untuk menghentikan proses kerusakan dan pengrusakan ini. Kelangsungan hidup terumbu karang dipengaruhi oleh tingkah laku manusia di darat yang dapat membawa berbagai tekanan kehidupan di pantai dan laut. Untuk mempertahankan dan menjaga kelestarian kehidupan terumbu karang, perlu dimengerti bagaimana pengaruh interaksi kegiatan manusia dengan kehidupan vegetasi yang berdampak pada keseimbangan kehidupan terumbu karang.

Salah satu bentuk interaksi kegiatan manusia dengan lingkungan yaitu kepedulian terhadap lingkungan. Menurut Weigel dalam Joshi (2012), kepedulian lingkungan dapat dianggap sebagai perhatian terhadap fakta-fakta dan perilaku dari diri sendiri dengan konsekuensi tertentu untuk lingkungan. Pramono (2012) menjelaskan bahwa kepedulian lingkungan adalah suatu kegiatan yang berupa aktivitas fisik, pikiran atau sumbangan dalam bentuk dana keuangan atau bentuk lainnya yang secara sungguh-sungguh diberikan dengan ikhlas untuk mewujudkan lingkungan hijau. Pramono (2012) juga

E-ISSN : 2615-2630 
menyatakan empat indikator kepedulian lingkungan yaitu 1) kegiatan pemikiran, 2) kegiatan fisik, 3) sumbangan dana, 4) sumbangan dalam bentuk lainnya.

Sudjana (2017) menjelaskan bahwa pemahaman dapat dibedakan kedalam tiga kategori, yaitu: 1) pemahaman terjemahan, mulai dari menerjemahkan kedalam arti yang sebenarnya dan menerapkan prinsipprinsip; 2) pemahaman penafsiran, ialah kemampuan menghubungkan bagianbagian terendah dengan yang diketahui berikutnya, menafsirkan ide-ide yang dipahami beserta konsekuensinya atau implikasi dalam kehidupan, mampu membuat generalisasi atau ringkasan, dan membedakan yang pokok dengan yang tidak pokok; 3) pemahaman ekstrapolasi, yang berarti kemampuan membuat estimasi dan prediksi tentang konsekuensi atau dapat memperluas persepsi dalam arti waktu, dimensi, kasus, ataupun masalahnya.

Selain dari pemikiran bentuk kepedulian juga dapat dilihat dari sumbangan. Menurut Pramono (2012), kepedulian lingkungan dapat dalam bentuk sumbangan dana yang ditunjukan untuk perbaikan lingkungan demi kesehatan, keindahan dan kebaikan bersama dengan mewujudkan lingkungan yang asri. Sumbangan yang dimaksud disini adalah bagaimana masyarakat menyumbangkan barang maupun uangnya untuk memfasilitasi perbaikan kerusakan terumbu karang. Sumbangan tersebut dapat berbentuk moril maupun materil.

Hal ketiga dari bentuk kepedulian yaitu tindakan. Dalam praktek seharihari bentuk kepedulian itu dapat berupa Jurnal Buana - Volume-2 No-5 2018 tindakan nyata secara fisik misalnya melakukan sesuatu untuk memperbaiki lingkungan apa saja yang cenderung akan bisa menjadi rusak/merugikan (Pramono, 2012). Berdasarkan pendapat para ahli tersebut, dapat ditarik kesimpulan yaitu kepedulian merupakan perhatian yang sungguh-sungguh dengan sikap atau perilaku yang dapat dilihat dari kegiatan pemikiran dalam menyelesaikan suatu masalah, sumbangan untuk memfasilitasi usaha perbaikan, dan aktivitas fisik berupa tindakan untuk memperbaiki kerusakan lingkungan tersebut.

\section{METODE PENELITIAN}

Jenis penelitian yang digunakan adalah deskriptif kualitatif. Adapun waktu penelitian yaitu pada bulan Agustus 2017. Sumber informan penelitian ditentukan dengan metode snowball sampling, yaitu teknik penentuan sampel yang mula-mula jumlahnya kecil kemudian membesar (Sugiyono, 2011). Teknik pengambilan sampel berdasarkan wawancara atau korespodensi. Metode ini meminta informasi dari sampel pertama untuk mendapatkan sampel berikutnya, demikian secara terus menerus hingga seluruh kebutuhan sampel penelitian dapat terpenuhi.

Jenis data dalam pengumpulan data yang digunakan pada penelitian ini adalah data primer dan data sekunder. Untuk lebih jelasnya dapat dilihat pada tabel 2: 
Tabel 2. Jenis Data, Sumber Data, dan Alat Pengumpulan Data

\begin{tabular}{|c|c|c|c|}
\hline $\begin{array}{l}\mathrm{N} \\
\mathrm{O}\end{array}$ & Jenis Data & $\begin{array}{c}\text { Sumber } \\
\text { Data }\end{array}$ & $\begin{array}{c}\text { Alat } \\
\text { Pengumpul } \\
\text { Data }\end{array}$ \\
\hline 1 & \begin{tabular}{ll}
\multicolumn{2}{l}{ Data Sekunder } \\
a. & Kondisi fisik \\
b. & Kondisi \\
& sosial
\end{tabular} & $\begin{array}{l}\text { - Kantor } \\
\text { Camat } \\
\text { - DKP }\end{array}$ & $\begin{array}{l}\text { Daftar } \\
\text { registrasi }\end{array}$ \\
\hline 2 & 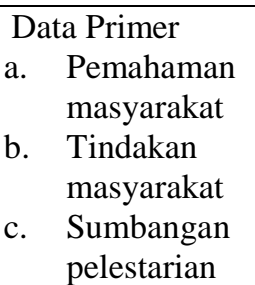 & - Informan & $\begin{array}{l}\text { - Pedoman } \\
\text { wawancara } \\
\text { - Kamera }\end{array}$ \\
\hline
\end{tabular}

Sumber: Pengolahan Data Primer 2018

Teknik pengambilan data adalah menggunakan observasi, wawancara dan dokumentasi. Untuk mendapatkan data yang valid, peneliti menggunakan trianggulasi data. Trianggulasi data adalah teknik pemeriksaan keabsahan data yang memanfaatkan sesuatu yang lain diluar data itu, untuk keperluan pengecekan atau pembanding terhadap data tersebut (Moleong, 2005). Untuk mendapatkan data yang valid, selain melalui wawancara, kuesioner dan observasi, peneliti menggunakan dokumen tertulis, arsip, dokumen sejarah, catatan resmi, catatan atau tulisan pribadi dan gambar maupun foto.

\section{HASIL DAN PEMBAHASAN}

Ancaman terhadap kerusakan terumbu karang merupakan hal serius yang memerlukan perhatian khusus dari segala pihak terutama masyarakat yang mendiami wilayah tersebut. Masyarakat dikatakan mengetahui ancaman yang akan terjadi pada terumbu karang apabila ia mengerti akan arti dari terumbu karang itu sendiri. Pemahaman akan arti terumbu karang menjadi masalah utama bagaimana tingkah laku masyarakat yang berdampak pada kelangsungan hidup ekosistem itu selanjutnya.

Pengetahuan masyarakat akan arti terumbu karang di Kecamatan Sikakap beragam. Sebagian besar masyarakat di Kecamatan Sikakap dapat menjelaskan bahwa karang merupakan makhluk hidup yang tumbuh dan berkembang biak, dan tidak jarang yang berpendapat bahwa karang merupakan benda mati, namun hanya beberapa masyarakat yang mengetahui bahwa terumbu karang merupakan hewan bukanlah tumbuhan. Pada umumnya masyarakat Kecamatan Sikakap telah mengetahui manfaat terumbu karang terutama dalam bidang perikanan.

Masyarakat Kecamatan Sikakap, khususnya nelayan tradisional dalam kegiatan penangkapan ikan bergantung pada keberadaan karang. Masyarakat juga mengetahui bahwa terumbu karang merupakan tempat berkembangnya ikan-ikan dan melakukan pemijahan. Hal tersebut dijelaskan oleh Bermin (20 tahun) pada wawancara tanggal 17 Agustus 2017.

“... kek nuobak ibara iba simaigi, nu gab aka bukuk. Set da malebei ta gaba. Kalulut bukuk kudduat iba. Oto tak anai bukuk, iba mabesik ta gaba"

Artinya:

“... kalau mau banyak dapat ikan, carilah dekat karang disana lebih mudah dapat ikannya. Karena terumbu karang itu tempat tinggal ikan-ikan juga. Jadi kalau tidak ada terumbu karang, ikan juga susah diperoleh" 
Adapun contoh bentuk penampakan terumbu karang di Kecamatan Sikakap dapat dilihat pada gambar 1 berikut.

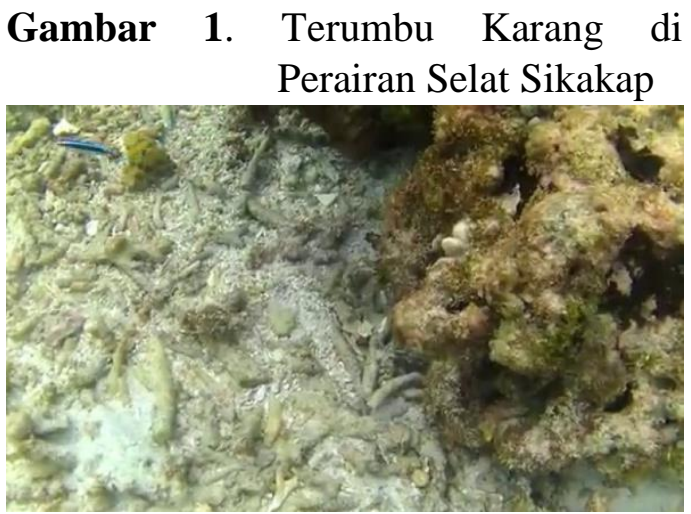

Sumber: Dokumentasi Penelitian

Aktivitas masyarakat yang sering berhubungan dengan habitat terumbu karang yaitu kegiatan penangkapan ikan. Masyarakat di Kecamatan Sikakap mengetahui adanya larangan terhadap eksploitasi hasil laut menggunakan bom dan racun. Masyarakat telah memahami akibat yang terjadi dari penggunaan bom dan racun tersebut berdampak pada rusak dan hancurnya terumbu karang. Hal tersebut disampaikan oleh Firman (25 tahun) pada wawancara tanggal 17 Agustus 2017.

"... urang mambom jo maracun tu kan tindakan yang salah tu. Lah jaleh ado hukumnyo untuak indak buliah pakai barang tu untuak malauik, hancua karang dek nyo. Kalau kadapekan yo dipanjaro lah hukuman e lai"

Artinya:

“... orang membom dan meracun (ikan) itu merupakan tindakan yang salah, sudah jelas ada hukumnya untuk tidak boleh menggunakan barang tersebut untuk melaut, hancur karang karenanya. Kalau kedapatan ya hukumannya dimasukkan ke penjara"

Jurnal Buana - Volume-2 No-5 2018
Di Kecamatan Sikakap masih ditemukan masyarakat yang menggunakan alat tangkap tradisional seperti tombak. Hal ini sesuai dengan penjelasan Jintar (46 Tahun) pada wawancara tanggal 15 Agustus 2017

“... may masibaga iba masih pakei tombak, baikbaik, jarik masisino"

Artinya:

“... kami memancing masih pakai tombak, pancing, jala dan menyelam"

Meskipun dikategorikan sebagai alat tangkap yang ramah lingkungan karena selektif namun pada kondisi tertentu dapat menjadi tidak ramah lingkungan, misalnya pengoperasiannya pada malam hari menyebabkan alat tangkap tersangkut di terumbu karang dan merusak permukaan karang (Kushima dan Miyasaka, 2003).

Aktifitas masyarakat lainnya yang juga memberikan tekanan pada kehidupan terumbu karang adalah kebiasaan membuang sampah ke laut. Masyarakat pada dasarnya mengetahui bahwa sampah yang dibuang ke laut dapat membahayakan ekosistem laut termasuk terumbu karang karena sampah dapat menutupi karang yang hidup di laut, yang mana keadaan demikian dapat mengakibatkan karang mati. Hal ini disampaikan oleh Adrian (29 tahun) pada wawancara tanggal 16 Agustus 2017.

“... maigi polak ribai ka koat bailiu masikatai bukuk, bukuk masikatai tak momoi matutuk"

Artinya:

“... banyaknya sampah yang dibuang ke laut menyebabkan tertimbunnya karang. Karang 
yang sudah tertimbun susah untuk hidup lagi”.

Kenyataan yang terjadi di Kecamatan Sikakap, banyak ditemukan sampah rumah tangga yang menutupi dasar laut tempat terumbu karang hidup dan berkembang biak. Hal tersebut dapat dilihat pada gambar 2 .

Gambar 2. Sampah di Perairan Selat Sikakap.

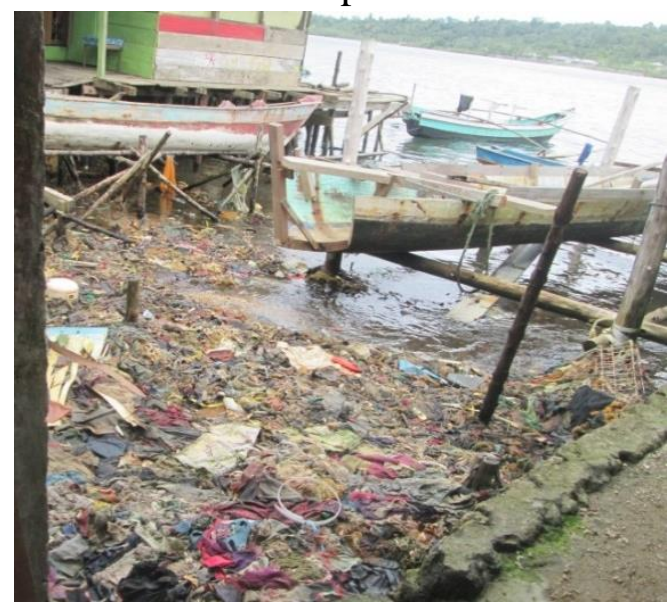

Sumber: Dokumentasi Penelitian 2017

Di Kecamatan Sikakap, sulitnya keberadaan batu kali sebagai bahan dasar bangunan memaksa masyarakat mengambil karang untuk dijadikan sebagai bahan pondasi bangunan. Aktifitas pengambilan karang tersebut dinilai wajar oleh masyarakat karena alasan karang yang diambil adalah karang yang telah mati. Penggunan batu karang sebagai bahan bangunan dikarenakan sulitnya sumber daya batu kali di daerah tersebut. Hal ini disampaikan oleh Sapri (49 tahun) pada wawancara tanggal 17 Agustus 2017.

“... lalep disenek maigi ngan pondasinya bukuk barakakoat, lipokat nia bukuk kaleleu tak momoi bukuk kakoat, tapoi masigaba bukuk kaleleu di senek mabesik"

Artinya:

Jurnal Buana - Volume-2 No-5 2018
“... bangunan disini kebanyakan berpondasikan batu karang, seharusnya menggunakan batu kali bukan menggunakan karang, tapi mencari batu kali itu disini susah"

Aktifitas masyarakat dan perahu juga dapat merusak dan menyebabkan karang menjadi patah karena benturan dan pergesekan badan perahu dengan permukaan karang. Dalam hal ini, masyarakat jarang yang mengetahui akibat dari perbuatan yang telah mereka lakukan. Hal tersebut sesuai dengan penjelasan Weski (26 tahun) pada wawancara tanggal 17 Agustus 2017.

“... jangkar yang bacampakan tu jatuahnyo kadang ka kasiak kadang ado lo yang ka karang. Ka baa lai, nyo jatuah se mah"

Artinya:

“... jangkar yang dibuang itu jatuhnya kadang ke pasir kadang ada pula yang ke karang. Mau bagaimana lagi, dia jatuh begitu saja"

Masyarakat Kecamatan Sikakap pada umumnya mengetahui resiko apabila rusaknya terumbu karang. Menurut masyarakat salah satu yang akan terjadi apabila rusaknya terumbu karang adalah berkurangnya jumlah hasil tangkapan ikan bahkan dapat menyebabkan sulitnya para nelayan untuk mendapatkan hasil tangkapan di kawasan perairan Sikakap. selain itu, masyarakat juga menjelaskan bahwa kerusakan terumbu karang berdampak pada abrasi pantai.

Dari penelitian yang telah peneliti lakukan, diketahui bahwa pertama, pemahaman masyarakat tentang ancaman kerusakan terumbu karang di Kecamatan Sikakap. Pemahaman 
masyarakat akan terumbu karang dinilai dari kemampuan masyarakat untuk mengartikan terumbu karang. Sudjana (2017) menjelaskan pemahaman menjadi tiga kategori yang pertama pemahaman terjemahan, yaitu kemampuan menerjemahkan kedalam arti yang sebenarnya, mengartikan, dan menerapkan prinsip-prinsip. Sebagian masyarakat di Kecamatan Sikakap menyebutkan bahwa terumbu karang adalah batu dan merupakan benda mati. Di lain sisi terdapat beberapa masyarakat yang telah mengetahui bahwa terumbu karang bukanlah benda mati melainkan makhluk hidup. Namun rata-rata mereka tidak tahu secara pasti terumbu karang termasuk hewan atau tumbuhan. Hal ini mengindikasikan bahwa secara umum masyarakat memahami bahwa terumbu karang bukan merupakan benda mati. Masyarakat juga mengetahui manfaat ekologis dari terumbu karang sebagai salah satu penyedia stok ikan di laut.

Tingkat pemahaman yang kedua adalah kemampuan interpretation. Sudjana (2017) menjelaskan bahwa pemahaman penafsiran adalah tingkat pemahaman seseorang telah mampu menghubungkan bagian terendah dengan yang diketahui berikutnya, menafsirkan ide-ide yang dipahami beserta konsekuensinya atau implikasi atau dalam kehidupan, mampu membuat generalisasi atau ringkasan, dan membedakan yang pokok dengan yang tidak pokok. Interpretasi digunakan untuk mengetahui bagaimana pemahaman masyarakat mengenai hal yang dapat membahayakan terumbu karang di Kecamatan Sikakap. Pada umumnya masyarakat di Kecamatan Sikakap telah memahami bahwa terdapat beberapa aktivitas sehari-hari yang dapat membahayakan terumbu karang. Aktivitas tersebut selain membahayakan habitat terumbu karang, juga telah dilarang dan memiliki peraturan dalam pelaksanaannya. Masyarakat menjelaskan bahwa beberapa kegiatan yang sering membahayakan terumbu karang dalam kesehariannya ialah penggunaan alat tangkap perikanan, membuang sampah ke laut, penambangan karang dan aktivitas sampan atau perahu.

Tingkat pemahaman masyarakat terhadap ancaman kerusakan terumbu karang yang ketiga adalah kemampuan extrapolation. Menurut Sudjana (2017) pemahaman extrapolation adalah kemampuan membuat estimasi dan prediksi tentang konsekuensi atau dapat memperluas persepsi dalam arti waktu, dimensi, kasus, ataupun masalahnya. Dari hasil penelitian, diketahui bahwa kerusakan terumbu karang akan mengakibatkan berkurangnya ikan di perairan Kecamatan Sikakap. Selain itu, masyarakat juga menyebutkan bahwa kerusakan terumbu karang juga dapat menyebabkan abrasi pantai.

Kedua, sumbangan masyarakat dalam upaya pelestarian terumbu karang di Kecamatan Sikakap. Pramono (2012), menjelaskan bahwa kepedulian lingkungan dapat dalam bentuk sumbangan dana keuangan yang ditujukan untuk perbaikan lingkungan demi kesehatan, keindahan dan kebaikan bersama dengan mewujudkan lingkungan yang asri. Sumbangan yang dimaksud adalah bagaimana masyarakat menyumbangkan barang atau uangnya guna memfasilitasi perbaikan kerusakan terumbu karang. Sumbangan yang diberikan dapat berbentuk moril 
maupun materil. Di Kecamatan Sikakap sumbangan yang telah masyarakat berikan terhadap kelangsungan hidup terumbu karang dinilai masih kurang. Hal tersebut dilihat dari tidak adanya bantuan yang telah masyarakat berikan terhadap perlindungan terumbu karang. Dari hasil penelitian yang telah dilakukan, diketahui bahwa masyarakat tidak pernah melaksanakan kegiatan perlindungan dan pemberdayaan terumbu karang. Sumbangan yang telah diberikan oleh masyarakat terhadap kelangsungan terumbu karang hanya dalam bentuk moril saja yaitu dukungan dan beberapa tindalan yang menjaga lingkungan. Sedangkan sumbangan dalam bentuk materil yaitu berupa barang ataupun dana untuk pelestarian, tidak pernah dilakukan oleh masyarakat di Kecamatan Sikakap. Di Kecamatan Sikakap terdapat suatu lembaga yang melindungi dan melestarikan sumber hayati laut terutama terumbu karang, namun dalam pelaksaannya masyarakat kurang bekerjasama bahkan hampir tidak terlibat dengan kegiatan tersebut. Kegiatan pelestarian hanya dilakukan oleh petugas dari COREMAP itu sendiri. Adapun kegiatan COREMAP yang terdapat di Kecamatan Sikakap pada saat dilakukannya penelitian, diketahui sudah tidak beraktivitas dalam pengembangan dan pemeliharaan terumbu karang lagi.

Ketiga, tindakan masyarakat terhadap sebab kerusakan terumbu karang di Kecamatan Sikakap. Menurut Pramono (2012), dalam praktek seharihari bentuk kepedulian dapat berupa tindakan nyata secara fisik misalnya melakukan sesuatu untuk memperbaiki lingkungan apa saja yang cenderung akan bisa menjadi rusak/merugikan. Di

Jurnal Buana - Volume-2 No-5 2018
Kecamatan Sikakap terdapat beberapa tindakan masyarakat yang memiliki pengaruh terhadap kelangsungan hidup terumbu karang diantaranya menangkap ikan dengan menggunakan bom dan racun sianida (potas), pembuangan sampah ke laut, penambangan batu karang, pembuangan jangkar. Dalam hal penggunaan alat tangkap perikanan, menurut Sukmara (2001) sumber ancaman kerusakan terumbu dari kegiatan illegal fishing yaitu 1) penangkapan ikan dengan bom, 2) menyemprotkan racun dan potasium pada daerah yang menjadi tempat hidup ikan yang biasanya berada di sekitar terumbu karang, 3) penggunaan jaring dasar dan trawl yaitu alat tangkap ikan berupa jaring yang ditarik menggunakan kapal menyusuri permukaan dasar perairan, 4) penggunaan bubu secara berlebihan, yaitu alat tangkap ikan berupa jebakan berbentuk kurungan seperti ruang tertutup sehingga ikan tidak dapat keluar. Di Kecamatan Sikakap sebagian besar masyarakatnya menggunakan alat tangkap yang masih bersifat tradisional seperti pancing dan jaring. Hanya beberapa pemilik armada yang memadai yang mampu menggunakan alat tangkap moderen.

Dari hasil penelitian diketahui bahwa aktivitas penangkapan ikan menggunakan alat tangkap yang membahayakan terumbu karang yaitu racun memang masih ada di Kecamatan Sikakap. Penggunaan alat tangkap ikan dengan racun tersebut dilakukan secara tersembunyi. Sedangkan penggunaan bom sudah tidak ada lagi. Adapun beberapa nelayan tradisional, selain menggunakan pancing dan jaring dalam kegiatan penangkapan ikan, mereka juga masih menggunakan tombak. 
Dalam penggunaannya mereka mengaku tidak merusak terumbu karang karena apabila tombak yang mereka gunakan mengenai karang maka tombak mereka sendiri akan hancur.

Penyebab kerusakan terumbu karang selanjutnya di Kecamatan Sikakap adalah pencemaran terumbu karang oleh sampah rumah tangga. Menurut Dahuri (2008), pembuangan sampah rumah tangga meningkatkan tingkat nutrisi dan racun di lingkungan terumbu karang. pembuangan limbah yang tidak diolah terlebih dahulu ke laut menambah nutrisi dan pertambahan alga yang berlebihan. Limbah kaya nutrisi dari sisa pembuangan sangat mengganggu, karena mereka meningkatkan perubahan besar dari struktur terumbu karang secara perlahan dan teratur. Alga mendominasi terumbu karang hingga melenyapkan karang pada akhirnya. Di Kecamatan Sikakap letak permukiman memberikan pengaruh pada aktivitas masyarakat yang membuang sampah ke laut. Permukiman masyarakat yang berdekatan dengan laut menyebabkan masyarakat memiliki kebiasaan membuang sampah ke laut. Hal tersebut mengakibatkan tertutupnya permukaan terumbu karang oleh sampah-sampah yang dibuang oleh masyarakat Kecamatan Sikakap.

Dari hasil penelitian diketahui bahwa tidak seluruh masyarakat di Kecamatan Sikakap yang memiliki kebiasaan membuang sampah ke laut. Di daerah perkampungan seperti Desa Taikako dan Desa Matobe, masyarakat memiliki permukiman jauh dari pantai sehingga kebiasaan membuang sampah ke laut tidak ditemukan di daerah ini. Sebaliknya permukiman penduduk di
Desa Sikakap berada di sekitar pantai bahkan tidak jarang berada di atas permukaan laut. Bentuk permukiman tersebut menyebabkan masyarakat terbiasa membuang sampah ke laut yang berujung pada pencemaran terhadap terumbu karang. Pada dasarnya pemerintah dan para petugas desa telah menberikan larangan dan peringatan bagi msyarakat yang membuang sampah ke laut. Bahkan telah pernah dibentuk TPS untuk warga agar tidak membuang sampah ke laut. Namun karena masih kurangnya kesadaran dan pemeliharaan maupun tanggung jawab terhadap TPS tersebut, mengakibatkan TPS yang telah dibentuk terbengkalai dan tidak difungsikan lagi.

Kegiatan pengrusakan karang selanjutnya ialah aktivitas penambangan karang. Menurut Berwich dalam Dahuri dkk (2008) penambangan karang sebagai bahan pondasi bangunan akan merusak secara langsung fisik dari terumbu karang dan akan mengurangi pondasi dari terumbu karang. DI Kecamatan Sikakap, karang seringkali digunakan masyarakat sebagai pengganti batu kali untuk bahan dasar bangunan. Banyak bangunan yang menggunakan batu karang sebagai bahan dasar terutama sebagai pondasi rumah dan pembuatan dam. Dari hasil penelitian diketahui bahwa aktivitas penambangan karang telah dilarang di Kecamatan Sikakap, namun masih terdapat beberapa masyarakat yang masih menggunakan karang sebagai alternatif pengganti batu kali. Hal tersebut terpaksa dilakukan oleh masyarakat karena sulitnya sumberdaya batu kali dan harganya yang mahal dibandingkan harga batu karang. Mahalnya harga batu kali tersebut 
disebabkan karena batu kali didatangkan dari luar Kecamatan Sikakap. Diketahui harga satu kubik batu kali adalah Rp 300.000 sedangkan untuk satu kubik batu karang hanya $\mathrm{Rp}$ 150.000 yang mana dua kali lipat lebih murah dari batu kali. Masyarakat menyebutkan bahwa karang yang diambil bukanlah karang yang hidup, melainkan karang yang sudah mati. Namun pada dasarnya kegiatan pengambilan karang baik yang masih hidup maupun yang sudah mati merupakan tindakan yang dapat merusak terumbu karang.

Aktifitas lalu lintas kapal mapun perahu/sampan juga tidak lepas dari penyebab terjadinya kerusakan terumbu karang di Kecamatan Sikakap. Menurut Sukmara (2001), sumber ancaman kerusakan terumbu karang oleh lalu lintas kapal diantaranya: 1) sauh atau jangkar kapal yang dibuang ke laut membentur permukaan terumbu karang secara terus menerus dan merusak permukaan terumbu karang, 2) kapal di perairan dangkal dapat menyebabkan pergesekan sisi bawah kapal dengan dasar laut atau terumbu karang, 3) alat pendorong perahu yang menggunakan tongkat dan bertumpu pada dasar laut. Di Kecamatan Sikakap kapal motor atau perahu menjadi salah satu alat angkut bagi masyarakat, terutama masyarakat dengan mata pencarian sebagai nelayan. Dari hasil penelitian diketahui bahwa saat pembuangan jangkar beberapa nelayan merasa bahwa perbuatannya tidak dapat mereka kendalikan karena jangkar yang dilepas tidak dapat dikontrol. Selain ketidakpedulian ketika pelepasan jangkar, masyarakat pemilik kapal motor maupun perahu mengaku jika saat pasang surut terjadi maka untuk melepaskan kapal motor/perahu yang mengalami kandas, mereka harus mendorong secara paksa kapal motor/ perahu menuju perairan yang lebih dalam. Kegiatan mendorong perahu tersebut sering menyebabkan perahu yang mereka miliki membentur dan bergesekan dengan permukaan karang. Benturan dan gesekan yang terjadi antara badan perahu dengan permukaan karang menyebabkan permukaan karang menjadi patah dan rusak.

Keempat, kepedulian masyarakat terhadap ancaman kerusakan terumbu karang di Kecamatan Sikakap. Pramono (2012), menjelaskan bahwa kepedulian lingkungan adalah suatu kegiatan yang berupa aktivitas fisik, pikiran atau sumbangan dalam bentuk dana keuangan atau bentuk lainnya yang secara sungguh-sungguh diberikan dengan ikhlas untuk mewujudkan lingkungan hijau. Pramono juga menyatakan empat indikator kepedulian lingkungan diantaranya yaitu 1) kegiatan pemikiran, 2) kegiatan fisik, 3) sumbangan dana, 4) sumbangan dalam bentuk lainnya. Di Kecamatan Sikakap, masyarakat yang memiliki kepedulian terhadap lingkungan terutama terumbu karang sebagian besar hanya dalam bentuk pemikiran saja. Hanya sedikit ditemukan masyarakat yang melakukan tindakan sebagai wujud nyata peduli terhadap kehidupan terumbu karang. Dari hasil penelitian yang telah dilakukan, diketahui bahwa kepedulian masyarakat yang tinggal di daerah perkampungan seperti Desa Taikako dan Desa Matobe lebih terlihat dibandingkan masyarakat yang tinggal di Desa Sikakap. Masyarakat di Desa Matobe dan Desa Taikako dalam hal membuang sampah jarang bahkan tidak 
pernah ke laut. Mereka mengaku selalu membakar sampah yang telah mereka kumpulkan terlebih dahulu.

Selain dalam hal pembuangan sampah, masyarakat Desa Taikako dan Desa Matobe juga lebih arif dalam penggunaan alat tangkap perikanan. Berbeda dengan penduduk Desa Sikakap, masyarakat Desa Taikako dan Desa Matobe masih menggunakan alat tangkap yang bersifat tradisional dalam kegiatan penangkapan ikan. Alat angkut yang mereka gunakan pun hanya berupa sampan/ perahu, sedangkan masyarakat Desa Sikakap telah menggunakan kapal dan jaring yang lebih besar. Dari hasil penelitian, diketahui perbedaan tingkah laku masyarakat antara Desa Sikakap dengan Desa Taikako dan Desa Matobe diketahui disebabkan berbedanya penduduk yang mendiami daerah tersebut. Penduduk Desa Sikakap pada umumnya merupakan para pendatang seperti suku Minang, Nias dan Batak yang telah mengenal budaya moderen. Sedangkan penduduk Desa Matobe dan Desa Taikako mayoritas keturunan suku Mentawai yang masih bersifat tradisional dan lebih menjaga alam.

\section{PENUTUP}

\section{Simpulan}

Berdasarkan hasil penelitian dan pembahasan dibagian terdahulu maka diambil kesimpulan sebagai berikut:

a. Secara umum masyarakat Kecamatan Sikakap telah mampu menjelaskan dengan baik arti dan fungsi terumbu karang, namun masyarakat masih kurang menyadari ancaman yang dapat mereka timbulkan kehidupan terumbu karang. b. Sumbangan oleh masyarakat terhadap kelangsungan hidup terumbu karang hanya dalam bentuk moril saja yaitu dukungan dan beberapa tindakan menjaga lingkungan. Sedangkan sumbangan dalam bentuk materil yaitu berupa barang ataupun dana untuk pelestarian, tidak pernah diberikan oleh masyarakat di Kecamatan Sikakap.

c. Tindakan masyarakat terhadap sebab kerusakan terumbu karang di Kecamatan Sikakap yaitu penyalahgunaan alat tangkap perikanan, pencemaran laut oleh sampah rumah tangga, penambangan karang, dan aktivitas perahu atau kapal motor. Sebagian besar tindakan tersebut merupakan aktivitas yang sering dilakukan terutama oleh masyarakat Desa Sikakap yang memiliki permukiman paling dekat dengan laut.

d. Kepedulian masyarakat terhadap ancaman kerusakan terumbu karang di Kecamatan Sikakap lebih ditunjukkan oleh masyarakat yang bertempat tinggal di perkampungan yang terbiasa mengumpulkan kemudian membakar sampah serta dalam penggunaan alat tangkap yang lebih ramah lingkungan, sedangkan masyarakat yang berada di pusat kecamatan sering membuang sampah ke laut dan menggunakan alat tangkap berbahaya sehingga menyebabkan tekanan terhadap terumbu karang di Kecamatan Sikakap. 


\section{Saran}

Berdasarkan penelitian dan kesimpulan yang dikemukakan di atas, maka peneliti memberikan saran sebagai berikut:

a. Masyarakat Kecamatan Sikakap diharapkan agar lebih meningkatkan kesadaran akan pentingnya terumbu karang bagi kehidupan sekarang dan anak cucu nanti.

b. Dalam kegiatan dan aktivitas sehari-hari yang berhubungan dengan lingkungan terutama terumbu karang, diharapkan masyarakat Kecamatan Sikakap dapat lebih bijaksana dan mempedulikan akibat dari tindakannya tersebut.

c. Diharapkan masyarakat Kecamatan Sikakap bekerjasama baik antar warga maupun dengan pemerintah untuk memperbaiki dan melestarikan terumbu karang di Kecamatan Sikakap.

\section{DAFTAR PUSTAKA}

Amin. 2009. Teumbu Karang: Aset yang Terancam (Akar Masalah dan Alternatif Solusi Penyelamatannya. Bekasi: Jurnal Terumbu Karang Vol 1, No: 2

Bandiyono, S., Ngadi \& Sudiyono. 2009. Kondisi Sosial Ekonomi Masyarakat di Lokasi COREMAP II Desa Sikakap, Kabupaten Kepulauan Mentawai Hasil BME. Jakarta: Coremap II-LIPI.

Christie, P. and A.T. White. 2007. Best Practices for Improved Govermance of Coral Reef
Marine Protected Areas. Coral Reefs, Vol 26.

Cicin-Sain B. and R. Knecht. 1998. Integrated Coastel Ocean Management: Concept and Practises. Island Press. Washington DC.

Dahuri, R., Rais, J., Ginting, SP., \& Sitepu. 2008. Pengelolaan Sumberdaya Wilayah Pesisir dan Lautan Secara Terpadu. Jakarta: PT Pradnya Paramita.

Djalal, Hasjim. 1995. Perjuangan Indonesia di Bidang Hukum Laut. Bandung: Bina Cipta.

Done, T.J., J.C, Ogden, W.J. Wiebe, and B.R. Rosen. 1996. Biodiversity and Ecosystem Function of Coral Reefs. John Wiley and Sons Ltd. U.K. 493p.

Hukom, Frensly \& Djuwariah. 2010. Monitoring Terumbu Karang Mentawai (Samukop, Bosua, Sikakap). Jakarta: COREMAP IILIPI.

Joshi, P. 2012. Effects of Environmental Concern \& Social Norms on Environmental Friendly Behavioral Intentions. Business Intelligenc Journal. Vol. 16. No. 2.

Kushima, J.A. and a. Miyasaka. 2003. Report on The Discussion to Manage The Usa of Lay Nets. State Hawaii. Departement of Land and Natural Resources. Division of Aquatic Resoursces. 22p.

Nash, S.V. 1989. Reef Diversity Index Survey Method for Nonspecialist Tropical Coastel Area management Newsletter. Philippines Vol 4, No: 3. 
Moberg, F. and C. Folke. 1999. Ecological Goods and Services of Coral Reef Ecosystem. Ecological Economic, Vol 29 No 2.

Moleong, Lexy j. 2005. Metodologi Penelitian Kualitatif. Bandung: Remaja Rosda Karya.

Pramono, I. C. W. 2012. Perilaku Wawasan Lingkungan Hijau Mahasiswa Sekolah Tinggi Ilmu Ekonomi Taman Siswa Jakarta. Sekolah Tinggi Ilmu Ekonomi Taman Siswa Jakarta: Jurnal Ekonomi. Tahun 28, No: 317

Sudjana, Nana. 2017. Penilaian Hasil Proses Belajar Mengajar. Bandung: PT Remaja Rosdakarya. Sugiyono. 2011. Metode Penelitian Kuantitatif, Kualitatif dan $R \& D$. Bandung: Afabeta.

Sukmara, A., A.J. Siahainenia \& C. Rotinsulu. 2001. Panduan Pemantauan Terumbu Karang Bebasis Masyarakat dengan Metode Manta Tow. Proyek Pesisir. Publikasi Khusus. Jakarta: Departemen Kelautan dan Perikanan \& Coastal Resources Center University of Rhode Island.

Suyarso. 2011. Potensi Sumber Daya Terumbu Karang Berbasiskan Citra Alos di Kawasan Pulau Pagai Sumatera Barat. Jurnal Segara Vol 7, No: 2.

Tesfamichael, D and T.J Pitcher. 2006. Multidiciplinary Evaluation of The Sustainability of Red Sea Fisheries using Rapfish. Fisheries Research, Vol 78.

Westmacott S., Teleki K., Wells S., \& West J., 2000. Pengelolaan Terumbu Karang yang Telah Memutih dan Rusak Kritis,
Diterjemahkan oleh Jan Hannim Steffen I. Jakarta: IUCN.

Zamanai, N.P and H.H. Madduppa, 2011. A Standard Criteria for Assesing the Health of Coral Reefs: Implications for Management and Conservations. J. Indonesia Coral Reefs, Vol 1, No 2. 